\title{
STRUCTURAL CONVERGENCE BETWEEN AFRICAN COUNTRIES: EMPIRICAL EVIDENCE
}

\author{
(iD) a) BAKO OUSMANE, Ali* \\ iD b) ŞIŞMAN, Mehmet \\ a) International Economics, Marmara University, Istanbul, Turkey. *Corresponding author \\ (bakoousmaneali@outlook.fr ) \\ b) Professor, Department of Economics Marmara University, Istanbul, Turkey.
}

\section{COPYRIGHT NOTICE:} the Creative Commons Attribution (CC BY) license (https://creativecommons.org/licenses/by/4.0/ ).

\section{CITE THIS PAPER:}

Bako Ousmane, Ali; Şişman, Mehmet (2022). "Structural Convergence between African Countries: Empirical Evidence" Journal of World Economy: Transformations \& Transitions (JOWETT) 1(03):13. DOI: https://doi.org/10.52459/jowett13130122

\begin{abstract}
This paper aims to investigate structural convergence in selected African countries over the period 1994-2019. Using panel data for 48 African countries and several estimation methods [PanelCorrected Standard Errors (PCSE), Feasible Generalized Least Squares (FGLS), tobit model, instrumental variable, and Granger non-causality], the results show the existence of the phenomenon of sectoral structural convergence in Africa, i.e. a greater similarity in sectoral structures while income gaps are narrowing. The paper also highlights the service sector's low relative productivity level and industrial sector's low labor force attractiveness despite a significant shift in labor from the agricultural sector and a higher level of relative productivity respectively. To address this issue, the development and acquisition of human and physical capital would be necessary to develop the industrial sector and increase the service sector's productivity.
\end{abstract}

\section{KEYWORDS}

Structural Convergence, Structural Transformation, Sectoral Relative Productivity Levels, African Economy. 


\section{INTRODUCTION}

The convergence theory, which states that lagging countries grow faster than leading countries, has been in the economic literature since Veblen (1915), Ramsey (1928), Viner (1950), Solow (1956), Gerschenkron (1962), Abramovitz (1979, 1986). More recently, authors such as Krugman (1991) and Wacziarg (2001) focused on structural convergence, another equally interesting aspect of convergence. According to Wacziarg (2001) "two countries are said to structurally converge if convergence in their per capita incomes is accompanied by convergence in their sectoral structure". This definition refers to sectoral structural convergence, limited to sectoral structure similarity. Absolute structural convergence refers to a process that extends beyond sectoral similarity and includes business cycle synchronization and foreign trade integration (Alexoaei and Robu 2018).

There are many reasons to be interested in the phenomenon of structural convergence.

First, the structural transformation of a country's economy is one of the main factors in economic development (Lewis, 1954; McMillan and Rodrik, 2011). Structural convergence is only the result of multiple converging structural transformations in several countries.

Second, structural convergence suggests that countries follow similar development paths characterized by increases and decreases by types of similar sectors as per capita incomes increase and those countries can converge towards a structural "steady-state", in which the sectoral composition of production becomes more uniform across countries.

Third, if shocks to the macroeconomy are sector-specific, structural convergence has implications on the international transmission of business cycles: it should give rise to increased international business cycle correlations (Imbs, 2000).

Fourth, understanding the factors that induce structural convergence can advance theory on a longterm dynamic model of specialization and international trade. The identification of links between the increase in structural similarity and changes in the relative abundance of factors can help to advance theoretical knowledge on the Heckscher-Ohlin model of trade. Similarly, if the intensity of bilateral trade has a negative impact on sectoral similarity, this can be considered as evidence of traditional specialization, if it affects it positively, it can be interpreted as an indication of the expansion of trade between similar countries (intraindustry).

Despite the importance of this topic, it has received little attention within the context of Africa. On the one hand, several studies address structural transformation issues in Africa, such as De Vries, Timmer, and De Vries (2015), McMillan and Harttgen (2014), Rodrik (2014), Barrett et al. (2017) but without empirically and 
explicitly studying structural convergence of African economies. On the other hand, there are also several studies on real and nominal convergence issues in Africa such as Cunado and De Gracia (2006) and, Hammouda et al. (2009) but did not focus on structural convergence. This paper, therefore, attempts to fill this gap by analyzing the phenomenon of structural convergence between African countries. Specifically, the purpose of this paper is to investigate whether there is a phenomenon of structural convergence among African countries using employment and value-added data in agricultural, industrial, and service sectors and identify sectors with low relative levels of productivity.

The rest of the paper is structured as follows: Section 2 examines the theoretical and empirical literature on structural convergence. Section 3 presents the data and the models. Section 4 presents the results and the discussions, while Section 5 concludes.

\section{STRUCTURAL CONVERGENCE: THEORETICAL AND EMPIRICAL LITERATURE.}

\subsection{Theoretical Literature}

According to Wacziarg (2001) and, Palan and Schmiedeberg (2010), the concept of structural convergence has received little attention in the existing literature. structural convergence on the theoretical level is a rather complex concept and on the empirical level it is also a phenomenon quite difficult to highlight, thus making its definitions neither too strict nor too precise and refers to a wide range of conditions that must be fulfilled by structurally converging economies and still remain open to be completed (Alexoaei and Robu 2018). Nevertheless, theoretical arguments in favor of structural (inter-sectoral) convergence can be derived from the combination of the three sectors hypothesis (Fisher, 1939, 1952; Colin and Plant 1940; Fourastié, 1949) and the Chenery (1960) convergence hypothesis followed by some theoretical extensions made to this hypothesis.

The three sectors hypotheses predicted that countries with similar developmental levels, will experience rapprochement and then similarity in inter-sectoral structures, but of course, whatever is the level of rapprochement, the structural convergence between several countries will never be absolute because of socioeconomic, cultural, and geographic differences (Chenery 1960).

Chenery convergence hypothesis (Chenery 1960), refers to the developmental model of countries, i.e. as a country's per capita income increases, production in the industrial sector, and then total production will also increase. This process will therefore lead to a convergence of the structure of economies of all countries experiencing an increase in per capita income, whether in terms of productivity by sector or share of employees by sector. Kuznets (1972) argued that the share of the primary sector is inversely correlated with per capita 
income, while the shares of other sectors are positively correlated. Consequently, the per capita income gap is one of the key determinants of the heterogeneity of economic structures between countries.

Structural convergence is also driven by market processes, namely forces on the demand side and on the supply side. Thus, according to Abegaz (2002) and Palan and Schmiedeberg (2010) structural convergence on the demand side results from the following complementary effects:

Engel's Law of the declining share of food in consumption: An increase in per capita income in developing countries is associated with a decrease in spending on food and therefore an increase in the spending on other goods and services. Thus, to respond to this increase in spending, the secondary and tertiary sectors have to adapt their production and call on more labor from the primary sector. Thus, in all developing countries which will experience this increase in per capita income, a certain sectoral similarity will emerge from these structural changes (Syrquin and Chenery 1989).

Lewis's (1954) hypothesis of the elastic supply of labor: This hypothesis considers a dualist economy in which a capitalist sector and a subsistence sector are opposed. Due to rural underemployment, urban unemployment, and population growth, this subsistence sector constitutes a source of an unlimited supply of labor for the capitalist sector. This labor absorption will substantially change the sectoral structure of the countries' economies, which will undergo this process towards a rapprochement, leading to structural convergence.

International homogenization of consumption: As globalization has affected all countries, this fact tends to homogenize consumption preferences. Thus, despite persistent inequalities between poor and rich countries, the composition of demand for consumer goods, especially manufactured goods and services, is becoming more homogenous at the international level (Sazanami, 1995; Ray, 1998). This situation acts in favor of structural convergence because productive structures everywhere must adapt to this new demand.

Industrial policy: The industrial policies implemented by the States to either substitute imports or boost exports according to internal or external demand also act as a driver for structural convergence (Puga and Venables, 1997; Pack, 2000). Industrial policies can also be analyzed as drivers to structural convergence on the supply side.

On the supply side, structural convergence is favored by the following factors:

Dynamic or latent comparative advantage (Krugman, 1987; Amsden, 1989; Grossman and Helpman, 1991; Redding, 1999; Lin and Monga, 2010; Lin, 2011). Dynamic comparative advantage is the comparative advantage that an economy can potentially obtain (and, arguably, should seek) in the long run. A dynamic 
comparative advantage can result from learning by doing and the adoption of new technologies. Countries that strive to achieve it will reduce their technological gap vis-à-vis advanced countries. Since factor endowments (physical and human) are the determinants of inter-sectoral structure, such changes on the supply side act in favor of structural convergence (Forstner and Balance, 1990; Lall, 1997; Timmer, 1998).

Technology Diffusion: Developing countries can borrow technologies without following the process of building the institutions that govern the design of that technology. Gerschenkron (1962) and Abramovitz $(1979,1986)$ highlighted the catch-up effect through the advantage of latecomers. Many developing countries have benefited from technological diffusion and an increased capacity to assimilate it. Attracting foreign direct investment and many other trade and industrial policies have been used to speed up technological diffusion (Evenson and Westphal, 1995; Lall, 1997; Ruttan, 2000). This technological diffusion acts positively for the reduction of the technological gap between the countries and therefore promotes inter-sectoral convergence.

Production cycles: the rise in labor cost in advanced countries encourages companies to make foreign direct investments in processing activities in less advanced countries where wages are lower to maintain competitiveness. The "flying geese" model of Japanese, Taiwanese, Korean, Hong Kong, and Singaporean investments in the less industrialized neighboring countries of Southeast Asia (Thailand, Malaysia, Indonesia, Philippines, China, and Vietnam) is a good example (Vernon, 1989; Sazanami, 1995).

Solowian-type growth models (Solow, 1956, 1957) predict that for countries with similar steady-state conditions, the convergence of per capita income and then that of sectoral labor productivity will occur. Countries with production levels below their potential would attract more capital, and thus develop faster than those which are more advanced.

Several authors have also used different methodologies to empirically highlight structural convergence between several countries, notably European, Asian, and American.

\subsection{Empirical literature}

Wacziarg (2001) uses sectoral employment data from two sources to calculate bilateral correlations to show structural convergence across 141 countries for nearly 40 industries. Using different estimation methods, he finds that a narrowing of the income gap is significantly associated with a greater similarity of economic structure, which is synonymous with structural convergence. Barrios, Barry, and Strobl (2002) highlight a process of structural convergence between European Union (EU) periphery countries using the Krugman Specialization Index (KSI) with sectoral employment data. With a slightly more elaborate methodology, they 
find results very similar to Wacziarg (2001). C. Longhi and Musolesi (2007) study the structural convergence between forty European cities. Using the method by Wacziarg (2001), they use sectoral employment and sectoral value-added data to test the relationship between structural similarity and real convergence. Their results are similar to those of Wacziarg (2001) and confirm the existence of a phenomenon of structural convergence between these European cities. Palan and Schmiedeberg (2010) investigated the structural convergence of 14 EU countries from 1970 to 2005 . Their analysis is based on employment data. They investigated inter-sectoral and inter-industry convergence, focusing on changes between the agricultural, manufacturing, and service sectors. They find a significant and rapid inter-sectoral convergence, accompanied by a mixed picture concerning inter-industry convergence. The results also show a general shift towards technologically advanced industries, while employment shares in traditional low-tech industries decrease. Based on sectoral employment shares, Albu (2012) studies the structural convergence between European countries (EU-27), Eastern European countries (EU-10), and Western European countries (EU-15) during the period 2000-2011. To assess changes in the economic structure, the author expresses the employment shares in the three sectors of the economy as a function of the Gross Domestic Product (GDP) per capita. His results show a process of structural convergence in the EU over the period analyzed, as GDP per capita increases. Marelli and Signorelli (2010) use a $\beta$ convergence test to test structural convergence in EU-27 countries from 1990 to 2007. The results show that convergence of sectoral structures is well established for the EU, the old members (EU-15), and for the new Central and Eastern Europe Countries (CEEC) members. For the European Monetary Union (EMU) countries, a divergence in sectoral structures seems to emerge for the entire period. Based on an analysis of 275 Portuguese counties over the period 1985-2003, Crespo and Fontoura (2007) studied the determinants of structural similarity in Portugal. They use employment data from these counts to estimate their structural similarity. The results show that there is an evolution towards more sectoral similarity over time between these regions. Also, the results show that the structural similarity between the Portuguese counties increases with geographical proximity, a common border, the similarity of factor endowments in terms of physical and human capital, and the similarity in terms of centrality and market size.

In addition to empirical evidence of structural convergence by sectoral employment shares, several authors have also used sectoral value-added shares (sectoral productivity), business cycle synchronization, and trade integration to highlight structural convergence between groups of countries and/or regions (Landesmann, 2000; Fagerberg, 2000; Gács, 2003; Gugler and Pfaffermayr, 2004; Abegaz, 2002, 2008; O'leary, 2003; Strat and Popovici, 2015; Di Berardino et al., 2017; Chong et al., 2017; Lazarev and Gregory, 2007; Crespo and Fontoura, 2007; Beck, 2013). 


\section{METHODOLOGY}

\subsection{Data}

To investigate empirically structural transformation and convergence in Africa, we use panel data for 48 countries over the period 1994-2019. The data are sourced from the World Bank's World Development Indicators (WDI) database and the Groningen Growth and Development Center (GGDC) PWT version 9.1 database. The database includes value added by sector ${ }^{1}$, employment by sector, population, GDP, Gross National Income (GNI), and gross savings.

\subsection{Empirical models for structural transformation in Africa}

To investigate empirically the structural transformation processes underway in African countries in terms of sectoral value-added and sectoral employment as a function of GDP per capita and inspired by Duarte and Restuccia (2010), Albu (2012), and Herrendorf, Rogerson, and Valentinyi (2014) we express the sectoral shares (employment and value-added in agriculture, industry, and service in Africa) in terms of GDP per capita.

\section{Sectoral share $[(v a, E m p) a g, \text { ind, serv }]_{i t}=\alpha_{0}+\alpha_{1} G D P C A P_{i t}+\varepsilon_{i t}(3-1)^{2}$}

To calculate the relative productivity level of each sector in the whole of Africa, we followed De Vries, Timmer, and De Vries (2015). We first calculate the sectoral productivity level, i.e. the value-added of each sector divided by the population engaged in that sector. Secondly, we calculate the productivity of the economy (Africa), i.e. the value-added of the entire economy divided by the total population engaged in the economy. The relative productivity level is calculated as the ratio of the productivity level of the sector to the productivity level of the whole economy. This index allows us to see what the productivity level of each sector represents in the entire economy.

\subsection{Empirical models for structural convergence between African countries}

To empirically investigate the existence of structural convergence in Africa, we estimate the following empirical models in the spirit of Wacziarg (2001) and Barrios, Barry, and Strobl (2002). We build a model that

\footnotetext{
${ }^{1}$ The agricultural (AG), industrial (IND), and service (SERV) sectors, based on the International Standard Industrial Classification (ISIC) developed by the United Nations Statistics Division (UNSD).

${ }^{2}$ Va: Value-added, Emp: Employment, ag: Agriculture, ind: İndustry, serv: service.
} 
relates the sectoral structure to the income gap to investigate whether the reduction in the income gap is associated with greater sectoral similarity.

This model is presented as follows:

$$
\begin{aligned}
& \operatorname{ksiVA~AG}_{\mathrm{ij}}(\mathrm{t})=\alpha_{0}+\alpha_{1} \operatorname{INCOMDIFF}_{\mathrm{ij}}(t)+\alpha_{2} \operatorname{POPDIFF}_{\mathrm{ij}}(\mathrm{t})+\alpha(t)+\varepsilon_{\mathrm{ij}}(\mathrm{t}) \\
& \operatorname{ksiVA~IND}_{\mathrm{ij}}(\mathrm{t})=\alpha_{0}+\alpha_{1} \operatorname{INCOMDIFF}_{\mathrm{ij}}(t)+\alpha_{2} \operatorname{POPDIFF}_{\mathrm{ij}}(\mathrm{t})+\alpha(t)+\varepsilon_{\mathrm{ij}}(\mathrm{t}) \\
& \operatorname{ksiVASERV}_{\mathrm{ij}}(\mathrm{t})=\alpha_{0}+\alpha_{1} \operatorname{INCOMDIFF}_{\mathrm{ij}}(t)+\alpha_{2} \operatorname{POPDIFF}_{\mathrm{ij}}(\mathrm{t})+\alpha(t)+\varepsilon_{\mathrm{ij}}(\mathrm{t}) \\
& \operatorname{ksiEMPAG}_{\mathrm{ij}}(\mathrm{t})=\alpha_{0}+\alpha_{1} \operatorname{INCOMDIFF}_{\mathrm{ij}}(t)+\alpha_{2} \operatorname{POPDIFF}_{\mathrm{ij}}(\mathrm{t})+\alpha(t)+\varepsilon_{\mathrm{ij}}(\mathrm{t}) \\
& \operatorname{ksiEMPIND}_{\mathrm{ij}}(\mathrm{t})=\alpha_{0}+\alpha_{1} \operatorname{INCOMDIFF}_{\mathrm{ij}}(t)+\alpha_{2} \operatorname{POPDIFF}_{\mathrm{ij}}(\mathrm{t})+\alpha(t)+\varepsilon_{\mathrm{ij}}(\mathrm{t}) \\
& \operatorname{ksiEMP~SERV}_{\mathrm{ij}}(\mathrm{t})=\alpha_{0}+\alpha_{1} \operatorname{INCOMDIFF}_{\mathrm{ij}}(t)+\alpha_{2} \operatorname{POPDIFF}_{\mathrm{ij}}(\mathrm{t})+\alpha(t)+\varepsilon_{\mathrm{ij}}(\mathrm{t})(3-7)
\end{aligned}
$$

Where $\operatorname{ksiVA~AG}_{\mathrm{ij}}(\mathrm{t})$ refers to the Krugman Specialization Index (Krugman, 1991) computed with value-added (VA) data from the agricultural (AG) sector between countries $i$ and $j$ at year $t$. We first evaluate the share of the value-added in the agricultural sector in the total value-added produced in the country $i$ at year $\mathrm{t}$ which we denote as shareVA $A G_{i}(\mathrm{t})$. We then evaluate the share of the agricultural sector value-added in the African region (country j), i.e. all the other African countries in our database except country $i$ at year $t$ as in $\underline{S}$. Longhi, Nijkamp, and Traistaru (2004) or Palan and Schmiedeberg (2010) for computing KSI. We note this value as shareVA $A G_{j}(\mathrm{t})$. The $\mathrm{ksiVA} \mathrm{AG}_{\mathrm{ij}}(\mathrm{t})$ will be equal to the absolute value of the difference between shareVA $A G_{i}(\mathrm{t})$ and $\operatorname{shareVA} A G_{j}(\mathrm{t})$.

$$
\operatorname{ksiVA~AG} \mathrm{ij}_{\mathrm{ij}}(\mathrm{t})=\left|\operatorname{shareVA} A G_{i}(\mathrm{t})-\operatorname{shareVA} A G_{j}(\mathrm{t})\right|
$$

ksiVA IND $\mathrm{Ij}_{\mathrm{ij}}(\mathrm{t})$ and $\mathrm{ksiVA} \mathrm{SERV}_{\mathrm{ij}}(\mathrm{t})$ are computed in the same way as $\mathrm{ksiVA} \mathrm{AG}_{\mathrm{ij}}(\mathrm{t})$ with respect to value-added data from the industrial sector and service sector. The KSI in equations (3-5), (3-6), and (3-7) are also computed in the same way as the previous ones but with sectoral employment data. The KSI takes a value of zero if the country $i$ has a perfectly identical sectoral structure to the rest of Africa, and a maximum value of 1 if it has no sectoral similarity with the rest of Africa.

$\operatorname{INCOMDIFF}_{\mathrm{ij}}(t)$ is the absolute value of the difference in GDP per capita between countries $\mathrm{i}$ and $\mathrm{j}$ at year $t$. 


$$
\operatorname{INCOMDIFF}_{\mathrm{ij}}(t)=\left|\operatorname{GDPpercapita}_{i}(\mathrm{t})-\operatorname{GDPpercapita}_{j}(\mathrm{t})\right|
$$

$\mathrm{POPDIFF}_{\mathrm{ij}}(\mathrm{t})$ is the absolute value of the difference in market size measured by population (POP) between countries $i$ and $j$ at year $t$.

$$
\operatorname{POPDIFF}_{\mathrm{ij}}(\mathrm{t})=\left|P O P_{i}(\mathrm{t})-P O P_{j}(\mathrm{t})\right|
$$

$\alpha(t)$ is a year-specific effect materialized by a set of time dummies, and $\varepsilon_{\mathrm{ij}}(\mathrm{t})$ is the usual error term. Since our dependent variable KSI is bound between 0 and 1, we estimate our equations in logarithmic form.

Equations (3-2) to (3-7) allow relating income convergence to sectoral similarity. If reduction in income gaps is associated with a reduction in gaps between sectoral structures then we are in a situation of structural convergence so the coefficient $\alpha_{1}$ will then have a positive and significant sign. If the coefficient $\alpha_{1}$ is negative, then we are in a situation of structural divergence where the reduction in income gaps is associated with greater sectoral heterogeneity. The second independent variable POPDIFF is a kind of control variable that allows seeing the effects of the reduction in domestic market size gaps, thus a positive sign of the coefficient $\alpha_{2}$ of this variable implies that the reduction in domestic market size gaps is associated with more sectoral similarity and a negative sign implies that the reduction in domestic market size gaps is associated with more sectoral heterogeneity.

As mentioned above, two countries are said to structurally converge if convergence in their per capita incomes is accompanied by convergence in their sectoral structure. Convergence of per capita income occurs if the difference or ratio of per capita income between the richest to the poorest country in each pair decreases. In our case, each pair consists of one of the 48 African countries (represented by index i), and another country that represents all other African countries (represented by index $\mathrm{j}$ ) except country i. Figure 1 presents the ratio of GDP per capita between two pairs of countries, the Africa- Rwanda pair and the South Africa-Africa pair (the richest country divided by the poorest country). Rwanda at the beginning of our study period had the lowest level of GDP per capita while South Africa had one of the highest GDP per capita, Figure 1, elaborated by authors, shows that the Africa/Rwanda and South Africa/Africa ratios are continuously declining. This decline implies that Rwanda, which was poorer than Africa, is converging toward Africa and Africa, which was poorer than South Africa, is converging toward South Africa. 
Figure 1: ratio of GDP/cap between the richest to the poorest country (Africa/Rwanda, South Africa/Africa)

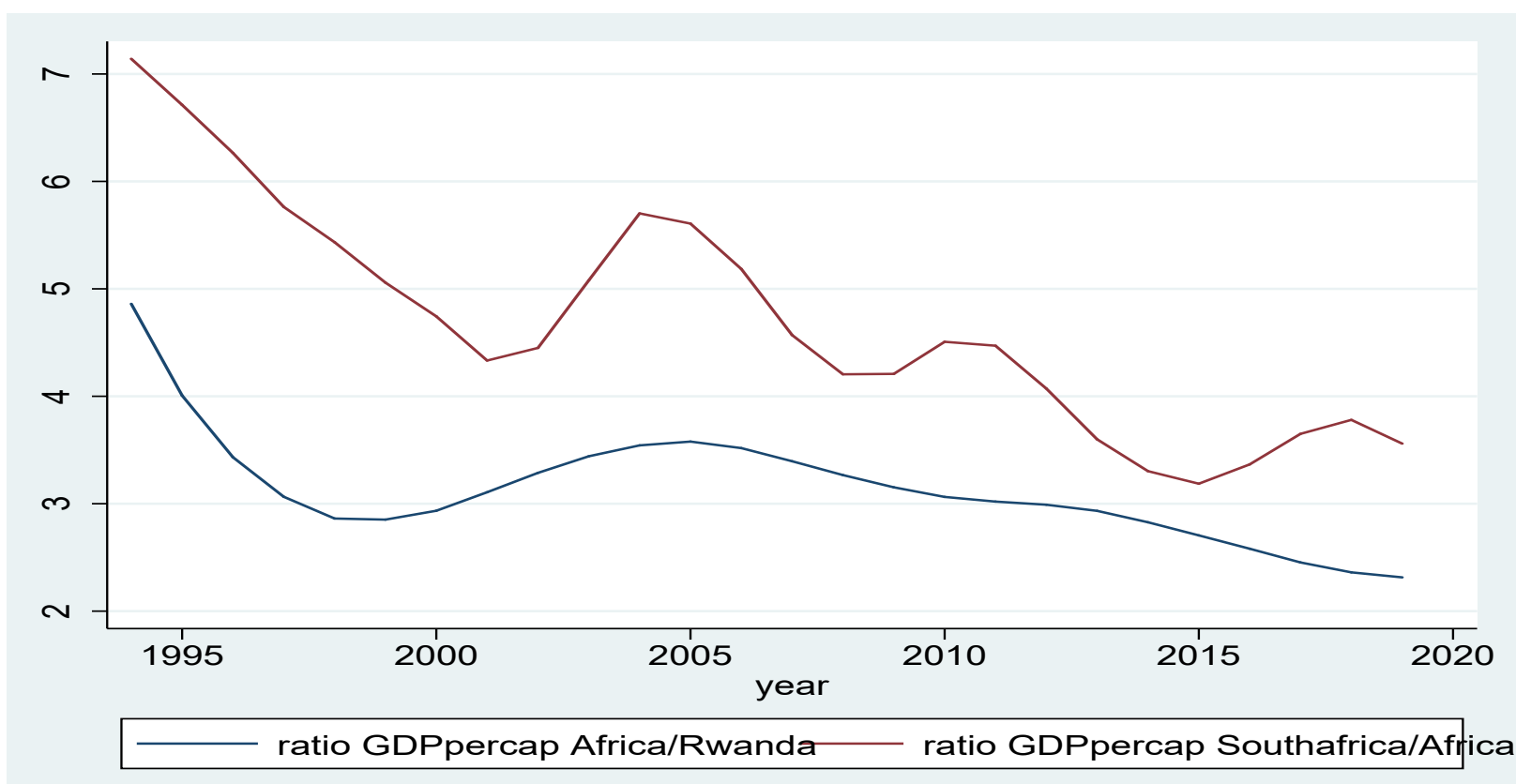

\section{RESULTS AND DISCUSSION}

\subsection{Structural transformation and sectoral relative productivity level in Africa}

The model simulation of equations (3-1) in Figures $\mathbf{2}$ and $\mathbf{3}$ made by authors shows a shift in labor and value-added from the agricultural sector toward the other two sectors (industry and services).

Figure 2: Share of the 3 sectors $^{3}$ in total employment (Emp) in Africa in $\%$ and logGDP/cap

${ }^{3}$ Agricultural ag, Industrial ind, and services serv. 


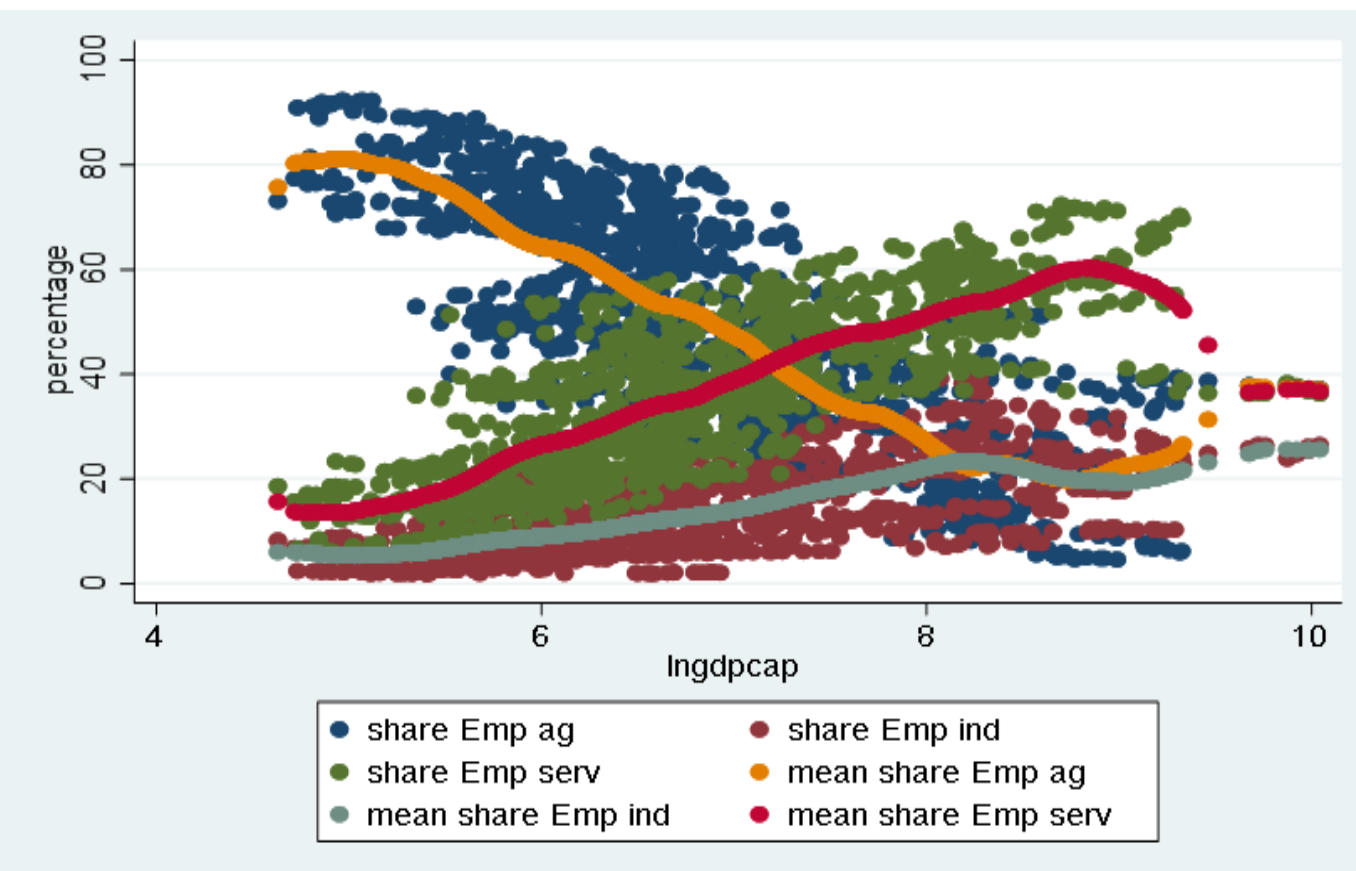

${ }^{4}$ in total value-added (VA) in Africa in $\%$ and $\log$ GDP $/$ cap

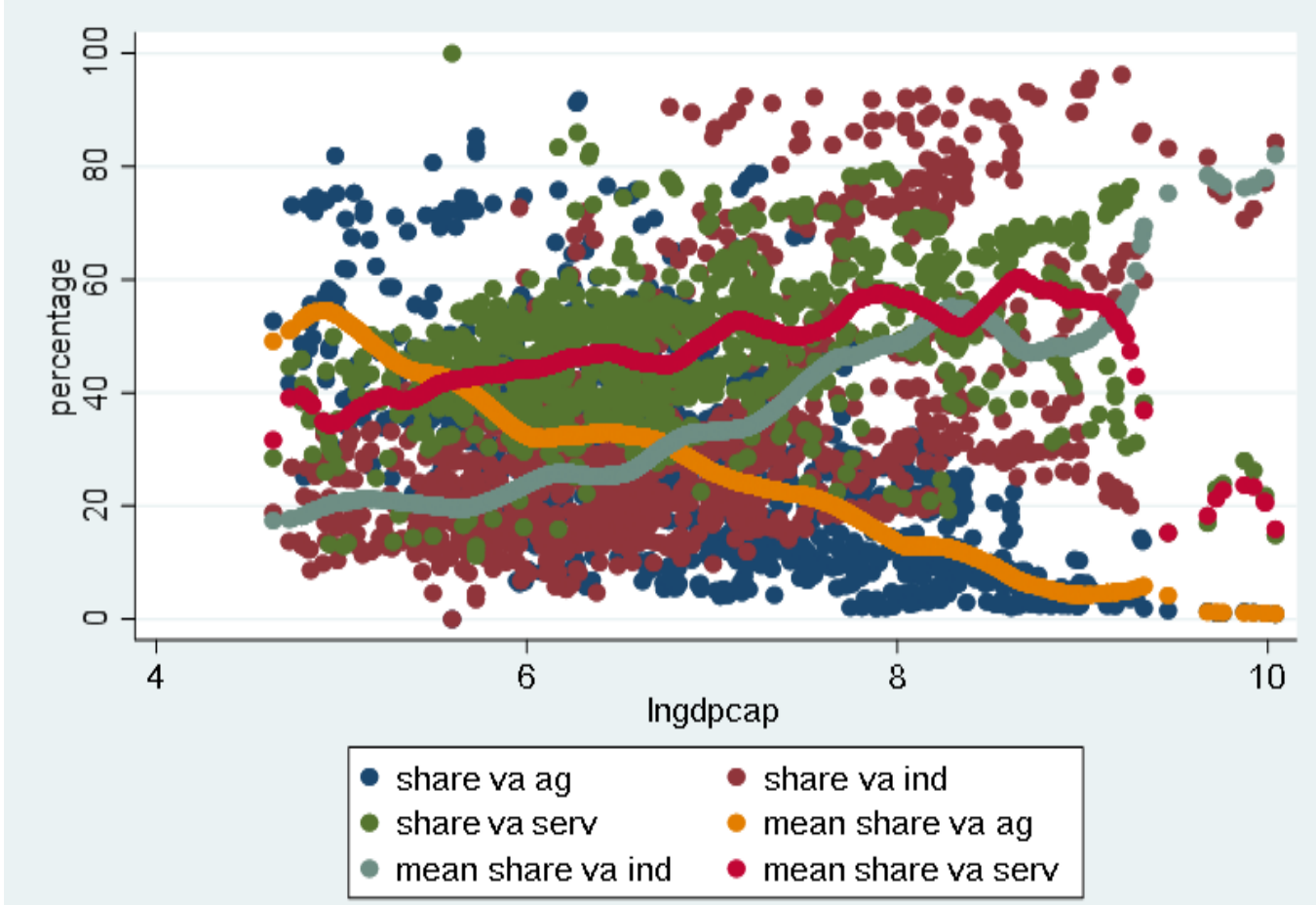

${ }^{4}$ Agricultural ag, Industrial ind, and services serv. 
close to 10. This shows that the service sector in Africa has a low level of relative productivity ${ }^{5}$ because while the share of labor is increasing considerably, the share of value-added is not following the same trend and seems to be decreasing. Based on the employment data, the industrial sector increases slightly, whereas considering the value-added data, it increases more significantly and even exceeds the service sector for values of lnGDP Per-capita close to 9. In contrast, for this same value for the employment data, the service sector is far above the industrial sector. This shows that the industrial sector in Africa has a better level of relative productivity than the service sector. This finding is characteristic of a structural transformation process, and that result is similar to Kuznets (1972), Duarte and Restuccia (2010), Albu (2012), Herrendorf, Rogerson, and Valentinyi (2014), McMillan and Harttgen (2014), and De Vries, Timmer, and De Vries (2015). According to Albu (2012), this shift of labor seems to show a general structural convergence process. While the GDP per capita is increasing, the sectoral employment and value-added shares in the three sectors follow a similar trend.

Table 1, elaborated by authors, shows that in 1994 the productivity level in agriculture was 0.32 times that of the total economy, while in the industry it was 2.6 times that of the total economy, and in the services sector, it was 1.6 times that of the total economy, the end of the period shows values similar to that of 1994 . Thus, the productivity level in the industrial sector in Africa, over the entire period is higher than that of the service sector and itself far higher than that of the agricultural sector.

Table 1: Sectoral relative productivity levels in Africa

\begin{tabular}{|l|c|c|c|}
\cline { 2 - 4 } \multicolumn{1}{c|}{} & \multicolumn{3}{c|}{ Relative productivity level } \\
\hline sear & & & \\
\hline sgriculture & 1994 & 2007 & 2017 \\
\hline Industry & 0,328 & 0,315 & 0,376 \\
\hline service & 2,672 & 3,257 & 2,553 \\
\hline Total economy & 1,62 & 1,332 & 1,278 \\
\hline
\end{tabular}

Table 1 shows that in 1994 the productivity level in the agriculture, industry and services sectors were $0.32,2.6$, and 1.6 times that of the total economy respectively. The trend remained almost the same in 2017, although the values for the industry show a peak around 2017 before declining towards its value at the beginning of the period, while the value for services has declined slightly. Thus, the productivity level in the industrial

${ }^{5}$ Considering only the workforce factor. 
sector in Africa, over the entire period is higher than that of the service sector and itself much higher than that of the agricultural sector.

This is because agricultural production is still done traditionally in many African countries and is also subject to climatic uncertainties. The productivity level of the service sector is higher than that of agriculture over the entire period, which is shown in the Figure 4, elaborated by authors. The diversity of activities in this sector and their permanent nature make its relative productivity much better than the agricultural one. The industrial sector has the best relative productivity of all three sectors (Figure 4), as the labor force is better qualified and has access to better physical capital. Most of the labor entering the service sector come from the agricultural sector, which is generally unskilled and usually engages in traditional service sector activities (security services, cleaning, parcel deliveries, dry cleaning, etc.). This would be an explanation for the fact that the productivity level of the service sector over the whole period is slightly decreasing despite the fact that this sector continues to receive labor (Figure 4). The productivity level of the industrial sector, after a slight increase, is also slightly continuously decreasing since the years 2005 (Figure 4).

Figure 4: Sectoral relative productivity levels in Africa (AG: agriculture, IND: industry, SERV: service)

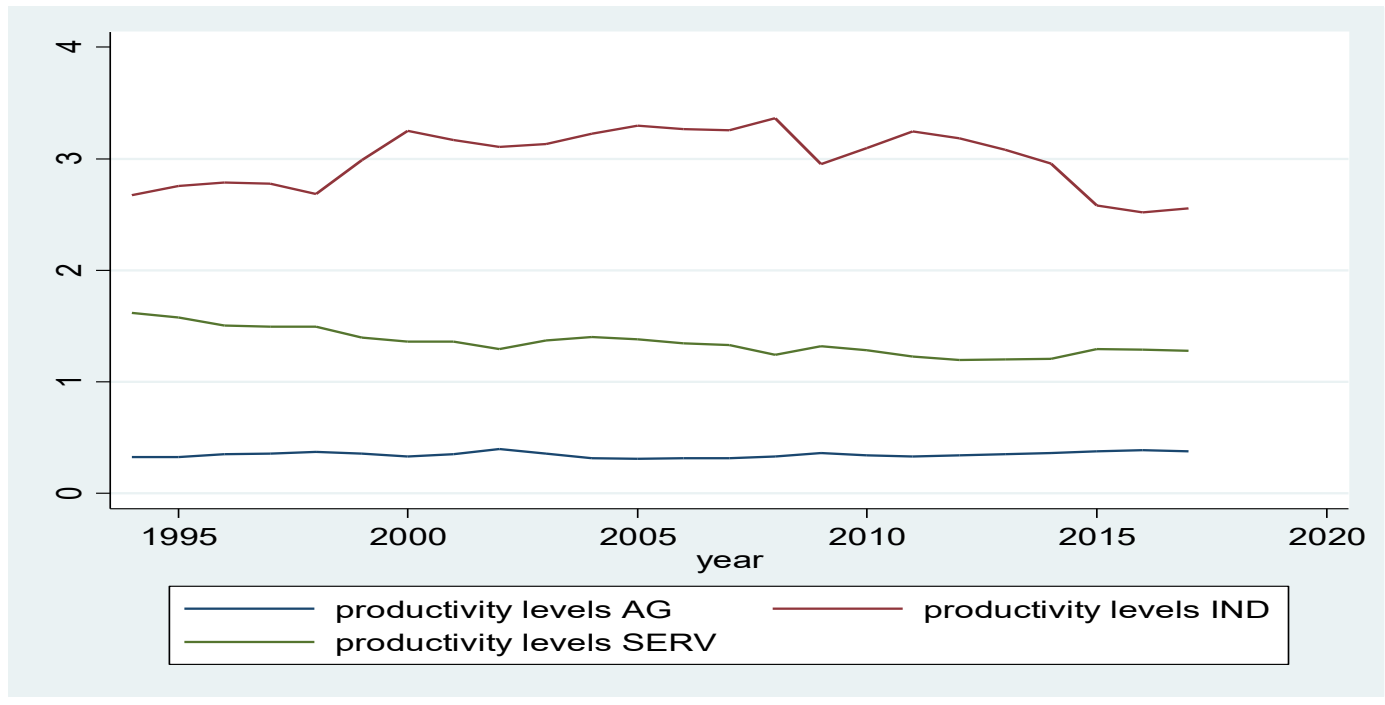

Page (2012) states that "deindustrialization after 1990 in Africa was characterized not only by a decline in the share of manufacturing output and employment but also by a decline in the diversity and sophistication of the region's manufacturing sectors". This partly explains this decline in the relative productivity level of the industrial sector. Also, the globalization of international trade, which became more pronounced in the 2000s, followed by the rapid industrialization of some countries, particularly in Asia, has put a strain on the weak African industrial sector, which could also explain the continuing decline in its productivity levels. According to McMillan and Zeufack (2021), the fact that the African industrial sector has a higher relative productivity level despite having the lowest labor share shows it is becoming more capital-intensive. 


\subsection{Structural convergence}

\subsubsection{Descriptive statistics}

In this section, we address equations (3-2) to (3-7) in order to investigate the structural convergence of African countries. The basic statistics for the annual frequency data for all the variables used in this section are summarized in Table 2 calculated by authors. It is worth noting that the database sample has a large number of available observations $(1,248)$. It should also be noted that the minimum and maximum values of all KSI ranging between 0 and 0.5 indicate a low degree of sectoral heterogeneity at first glance, as a KSI close to 0 is synonymous with sectoral homogeneity.

Table 2: Descriptive Statistics for all the variables used in this section

\begin{tabular}{lrrrrr}
\hline Variable & Obs & Mean & Std. Dev. & Min & Max \\
\hline ksiEmpAG & 1248 & .191 & .115 & .001 & .514 \\
ksiEmpIND & 1248 & .064 & .05 & 0 & .276 \\
ksiEmpserv & 1248 & .132 & .082 & 0 & .375 \\
ksivaAG & 1197 & .15 & .116 & 0 & .638 \\
ksivaIND & 1197 & .164 & .116 & 0 & .572 \\
ksivaSERV & 1102 & .137 & .134 & 0 & .531 \\
incomdiff & 1248 & 6.576 & 1.226 & -1.907 & 9.963 \\
popdiff & 1248 & 20.597 & .199 & 19.958 & 20.958 \\
savingcapdiff & 1248 & 9.72 & .632 & 8.123 & 10.647 \\
\hline
\end{tabular}

Table 3, calculated by authors, shows pairwise correlations between variables. We observe a positive and significant correlation between incomdiff and all the KSI. This seems to suggest that greater sectoral similarities accompany narrower income gaps. However, correlation does not necessarily mean causality. The variables popdiff and savingcapdiff ${ }^{6}$ show mixed correlations with the different KSI. The variable savingcapdiff shows a positive and significant correlation with the variable incomdiff, which augurs well with its use as an instrument.

\footnotetext{
${ }^{6}$ This variable saving per capita difference is computed in the same way as incomdiff but with per capita saving data.
} 
Table 3: Pairwise correlations between all the variables used in this section

Variables

(1)

(2)

(3)

(4)

(5)

(6)

(7)

$(8)$

(9)

\begin{tabular}{|c|c|c|c|c|c|c|c|c|c|}
\hline (1) ksiEmpAG & 1.000 & & & & & & & & \\
\hline (2) ksiEmpIND & $0.737 * * *$ & 1.000 & & & & & & & \\
\hline (3) ksiEmpserv & $0.891 * * *$ & $0.376 * * *$ & 1.000 & & & & & & \\
\hline (4) ksivaAG & $0.056^{*}$ & -0.021 & $0.093 * * *$ & 1.000 & & & & & \\
\hline (5) ksivaIND & $0.054 *$ & $0.181 * * *$ & 0.012 & $0.203 * * *$ & 1.000 & & & & \\
\hline (6) ksivaSERV & $0.383 * * *$ & $0.407 * * *$ & $0.302 * * *$ & $0.155 * * *$ & $0.511 * * *$ & 1.000 & & & \\
\hline (7) incomdiff & $0.421 * * *$ & $0.379 * * *$ & $0.358 * * *$ & $0.153 * * *$ & $0.163 * * *$ & $0.181 * * *$ & 1.000 & & \\
\hline (8) popdiff & 0.010 & 0.028 & -0.010 & $0.047 *$ & $0.065 * *$ & $0.053^{*}$ & $0.386 * * *$ & 1.000 & \\
\hline (9) savingcapdiff & -0.027 & $-0.047^{*}$ & -0.018 & -0.017 & $0.080 * * *$ & 0.037 & $0.324 * * *$ & $0.701 * * *$ & 1.000 \\
\hline
\end{tabular}

\subsubsection{Unit-root test}

Tables 4 show the unit root test results by authors' estimations. The null hypothesis of unit root is rejected for all variables by the Levin-Lin-Chu unit-root test and Fisher-type unit-root test based on augmented Dickey-Fuller (ADF) tests, implying that all are stationary. This means that the mean and variance of those variables do not change systematically over time.

Table 4: Levin-Lin-Chu and Fisher-Type (ADF) unit-root test results.

\begin{tabular}{|l|l|l|l|l|l|l|}
\hline \multicolumn{1}{|c|}{ Variables } & ksiEmp AG & ksiEmpIND & ksiEmpServ & incomdiff & popdiff & saving/capdiff \\
Statistics & & & & & & \\
\hline $\begin{array}{l}\text { Inverse chi- } \\
\text { squared(96) } \\
\text { Fisher-type } \\
\text { (ADF) test }\end{array}$ & $226.7809^{* * *}$ & $215.7137^{* * *}$ & $216.0152^{* * *}$ & $352.3742^{* * *}$ & $814.7762^{* * *}$ & $258.2050^{* * *}$ \\
\hline $\begin{array}{l}\text { Adjusted t* } \\
\text { Statistic Levin- } \\
\text { Lin-Chu test }\end{array}$ & $-2.923^{* * *}$ & $-4.276^{* * *}$ & $-1.970^{* *}$ & $-3.172^{* * *}$ & $-1.3 \mathrm{e}+02^{* * *}$ & $-3.1875^{* * *}$ \\
\hline
\end{tabular}




\subsubsection{Panel-corrected standard errors (PCSE) method results.}

To investigate the existence of structural convergence between African economies, we run fixed-effect ${ }^{7}$ regressions of the KSI indexes on the values of real convergence and domestic market size (incomdiff and popdiff), after which we perform tests of autocorrelation, heteroscedasticity and crossectional dependence. Tests reveal that the models suffer from autocorrelation and heteroscedasticity. We circumvent these problems by using the panel-corrected standard errors (PCSE) method as $\mathrm{N}>\mathrm{T}^{8}$ with $\mathrm{N}$ : number of countries and $\mathrm{T}$ : number of years. The results of the estimation of (3-2) to (3-7) are estimated by authors and reported in Tables 5 and 6 which show that a shrinking income gap ceteris paribus, is significantly linked to greater similarity in economic structure.

Table 5: PCSE estimates with employment data for Africa [equations (3-5), (3-6) and (3-7)]

\begin{tabular}{lccc}
\hline VARIABLES & $(1)$ & $(2)$ & $(3)$ \\
ksiEmpAG & ksiEmpIND & ksiEmpserv \\
\hline incomdiff & $0.0491^{* * *}$ & $0.0192^{* * *}$ & $0.0303^{* * *}$ \\
popdiff & $(0.00373)$ & $(0.00131)$ & $(0.00253)$ \\
& $-0.0673^{* * *}$ & $0.0235^{* *}$ & $-0.0930^{* * *}$ \\
Observations & $(0.0231)$ & $(0.00977)$ & $(0.0171)$ \\
R-squared & 1,248 & 1,248 & 1,248 \\
Number of countrinum & 0.221 & 0.177 & 0.168 \\
\hline
\end{tabular}

Standard errors in parentheses, $* * * \mathrm{p}<0.01,{ }^{*} \mathrm{p}<0.05, * \mathrm{p}<0.1$

Table 6: PCSE estimates value-added data for Africa [equations (3-2), (3-3) and (3-4)]

\begin{tabular}{lccc}
\hline \multirow{2}{*}{ VARIABLES } & $(1)$ & $(2)$ & $(3)$ \\
\hline incomdiff & ksivaAG & ksivaIND & ksivaSERV \\
\hline \multirow{2}{*}{ popdiff } & $0.0189^{* * *}$ & $0.0146^{* * *}$ & $0.0218^{* * *}$ \\
& $(0.00197)$ & $(0.00216)$ & $(0.00332)$ \\
Observations & $0.148^{* * *}$ & $-0.101^{* *}$ & $-0.116^{* * *}$ \\
R-squared & $(0.0406)$ & $(0.0469)$ & $(0.0272)$ \\
Number of countrinum & 1,197 & 1,197 & 1,102 \\
& 0.064 & 0.069 & 0.041 \\
\hline
\end{tabular}

Standard errors in parentheses, ${ }^{* * *} \mathrm{p}<0.01,{ }^{* *} \mathrm{p}<0.05,{ }^{*} \mathrm{p}<0.1$

\footnotetext{
${ }^{7}$ The Hausman test which rejects the null hypothesis for all sectors motivates this choice.

${ }^{8} \mathrm{~N}=48$ and $\mathrm{T}=26$.
} 
Indeed, the positive and significant coefficients of incomdiff indicate the structural convergence of African economies using both sectoral employment data and sectoral value-added data ${ }^{9}$. Market size differences, on the other hand, once controlling for incomdiff, appear to act against the similarity of sectoral structures. Indeed, the negative and significant signs of the popdiff ${ }^{10}$ coefficients indicate this ${ }^{11}$.

\subsubsection{African sub-regional features of structural convergence}

In this section, we investigate whether the evidence of structural convergence found in the previous section is only driven by specific subsets of the sample, or whether it is a reality across all the African continent? For this purpose, we consider 5 Regional Economic Communities (RECs) on the African continent for which we estimate the equations from (3-2) to (3-7) with the Feasible Generalized Least Squares (FGLS) estimation method because for the different RECs $\mathrm{T}>\mathrm{N}$. These 5 RECs ${ }^{12}$ are Arab Maghreb Union (AMU), Economic Community of Central African States (ECCAS), Economic Community of West African States (ECOWAS), Intergovernmental Authority on Development (IGAD) and the East African Community (EAC), Southern African Development Community (SADC).

For the AMU community, the estimation results made by authors and reported in Tables $\mathbf{7}$ and 8 are mixed. Indeed, the results for sectoral value-added data (Table 8) are very similar to those of the previous section, namely a positive and significant coefficient of incomdiff for all three sectors, showing structural convergence, and a negative and significant coefficient of popdiff for all three sectors, showing that market size difference act against the similarity of the sectoral structures. The results of the sectoral employment data (Table 7) show a partial structural divergence. Indeed, a negative and significant coefficient of incomdiff for the agricultural and services sector shows that a reduction in income gap, ceteris paribus, is significantly related to greater heterogeneity of these sectoral structures. For the industrial sector, the coefficient remains positive and significant, indicating the structural convergence in this sector. A positive and significant coefficient of popdiff for all three sectors shows that the difference in market size favors the similarity of sectoral structures.

\footnotetext{
${ }^{9}$ These results are very similar to those of Wacziarg (2001), Barrios, Barry, and Strobl (2002) and C. Longhi and Musolesi (2007).

${ }^{10}$ Except for ksiEmpIND and ksivaAG where the difference in market size acts positively for the similarity of sectoral structures.

${ }^{11}$ These results are very similar to those of Barrios, Barry, and Strobl (2002).

${ }^{12}$ List of countries by RECs in appendix.
} 
Table 7: FGLS estimates employment data for AMU [equations (3-5), (3-6) and (3-7)]

\begin{tabular}{lccc}
\hline \multirow{2}{*}{ VARIABLES } & $(1)$ & $(2)$ & $(3)$ \\
incomdiff & ksiEmpAG & ksiEmpind & ksiEmpserv \\
popdiff & $-0.0117^{* * *}$ & $0.00797^{* * *}$ & $-0.0190^{* * *}$ \\
& $(0.00317)$ & $(0.00154)$ & $(0.00350)$ \\
Observations & $0.0208^{* * *}$ & $0.00993^{* * *}$ & $0.00716^{* * *}$ \\
Number of countrinum & $(0.00190)$ & $(0.000919)$ & $(0.00209)$ \\
& 130 & 130 & 130 \\
\hline
\end{tabular}

Standard errors in parentheses, $* * * \mathrm{p}<0.01, * * \mathrm{p}<0.05, * \mathrm{p}<0.1$

Table 8: FGLS estimates value-added data for AMU [equations (3-2), (3-3) and (3-4)]

\begin{tabular}{lccc}
\hline \multirow{2}{*}{ VARIABLES } & $(1)$ & $(2)$ & $(3)$ \\
\hline incomdiff & ksiVAAG & ksiVAind & ksiVAserv \\
& $0.00919^{* * *}$ & $0.0391^{* * *}$ & $0.0406^{* * *}$ \\
popdiff & $(0.00258)$ & $(0.0132)$ & $(0.0136)$ \\
& $-0.00935^{* * *}$ & $-0.0326^{* * *}$ & $-0.0465^{* * *}$ \\
Observations & $(0.00154)$ & $(0.00788)$ & $(0.00795)$ \\
Number of countrinum & 125 & 125 & 115 \\
\hline
\end{tabular}

Standard errors in parentheses, $* * * \mathrm{p}<0.01, * * \mathrm{p}<0.05, * \mathrm{p}<0.1$

The partial structural divergence observed in the AMU can be explained by the small size of the database, but also by the important differences in factor endowment and in developmental options of the countries of that union. Algeria is endowed with oil and gas resources and has opted since its independence for industrial development, Egypt still has an agricultural sector that employs more than $20 \%$ of the workforce while Morocco and Tunisia are more tourism-oriented. The global structural convergence highlighted by Wacziarg (2001) no longer exists when considering only OECD ${ }^{13}$ countries, this seems to be the case for our results with AMU as this community is relatively richer on the continent when compared to others. This result is in line with findings from Imbs and Wacziarg (2000), who showed that rich countries appear to be in a stage of sectoral specialization, while others are in a stage of sectoral diversification.

${ }^{13}$ Organization for Economic Co-operation and Development. 
For the ECCAS community (Tables 9 and 10, estimated by authors), despite a positive sign in almost all the incomdiff coefficients, their non-significance means no conclusion can be drawn, except for the data on value-added of the industrial sector, which shows a positive and significant coefficient indicating structural convergence.

Table 9: FGLS estimates employment data for ECCAS [equations (3-5), (3-6) and (3-7)]

\begin{tabular}{lccc}
\hline \multirow{2}{*}{ VARIABLES } & $(1)$ & $(2)$ & $(3)$ \\
ksiEmpAG & ksiEmpind & ksiEmpserv \\
\hline popdiff & 0.00328 & 0.00322 & 0.00104 \\
& $(0.00421)$ & $(0.00221)$ & $(0.00416)$ \\
Observations & $0.0765^{* * *}$ & $0.0362^{* * *}$ & $0.0325^{* * *}$ \\
Number of countrinum & $(0.00852)$ & $(0.00447)$ & $(0.00842)$ \\
\hline
\end{tabular}

Standard errors in parentheses, ${ }^{* * *} \mathrm{p}<0.01,{ }^{* *} \mathrm{p}<0.05, * \mathrm{p}<0.1$

Table 10: FGLS estimates value-added data for ECCAS [equations (3-2), (3-3) and (3-4)]

\begin{tabular}{lccc}
\hline VARIABLES & $(1)$ & $(2)$ & $(3)$ \\
ksivaAG & ksivaIND & ksivaSERV \\
\hline incomdiff & 0.00237 & $0.0314^{* * *}$ & -0.00173 \\
\multirow{2}{*}{ popdiff } & $(0.00742)$ & $(0.00582)$ & $(0.00760)$ \\
& $0.0450^{* * *}$ & $0.0600^{* * *}$ & $0.0388^{* *}$ \\
Observations & $(0.0146)$ & $(0.0115)$ & $(0.0152)$ \\
Number of countrinum & 240 & 240 & 220 \\
\hline
\end{tabular}

Standard errors in parentheses, $* * * \mathrm{p}<0.01,{ }^{* *} \mathrm{p}<0.05, * \mathrm{p}<0.1$

For the remaining communities, namely ECOWAS, IGAD+EAC, SADC, structural convergence is a widely shared reality for all data (employment and value-added, Tables 11 to 16, estimated by authors). The difference between market sizes is sometimes in favor and sometimes against sectoral similarity. The coefficient implying a structural divergence in Table $\mathbf{1 5}$ for SADC with value added data is certainly due to significant industrial gaps in this community, as countries such as South Africa, Botswana, and Mauritius show significant differences in industrial value-added with other countries in the community. 
Table 11: FGLS estimates employment data for ECOWAS [equations (3-5), (3-6) and (3-7)]

\begin{tabular}{lccc}
\hline \multirow{2}{*}{ VARIABLES } & $(1)$ & $(2)$ & $(3)$ \\
incomdiff & KsiEmpAG & ksiEmpind & ksiEmpServ \\
\multirow{2}{*}{ popdiff } & $0.0483^{* * *}$ & $0.00533^{* *}$ & $0.0393^{* * * *}$ \\
& $(0.00574)$ & $(0.00211)$ & $(0.00430)$ \\
Observations & 0.00364 & $0.0103 * * *$ & $-0.00916^{* *}$ \\
Number of countrinum & $(0.00584)$ & $(0.00214)$ & $(0.00437)$ \\
\hline
\end{tabular}

Standard errors in parentheses, ${ }^{* * *} \mathrm{p}<0.01,{ }^{* *} \mathrm{p}<0.05, * \mathrm{p}<0.1$

Table 12: FGLS estimates value-added data for ECOWAS [equations (3-2), (3-3) and (3-4)]

\begin{tabular}{lccc}
\hline \multirow{2}{*}{ VARIABLES } & $(1)$ & $(2)$ & $(3)$ \\
ksivaAG & ksivaIND & ksivaSERV \\
\hline incomdiff & $0.0353^{* * *}$ & $0.0281^{* * *}$ & $0.0237^{* * *}$ \\
\multirow{2}{*}{ popdiff } & $(0.00828)$ & $(0.00514)$ & $(0.00501)$ \\
& $0.0322^{* * *}$ & $0.0111^{* *}$ & 0.00543 \\
Observations & $(0.00830)$ & $(0.00516)$ & $(0.00519)$ \\
Number of countrinum & 384 & 384 & 354 \\
\hline
\end{tabular}

Standard errors in parentheses, ${ }^{* * *} \mathrm{p}<0.01,{ }^{* *} \mathrm{p}<0.05,{ }^{*} \mathrm{p}<0.1$

Table 13: FGLS estimates employment data for IGAD+EAC [equations (3-5), (3-6) and (3-7)]

\begin{tabular}{lccc}
\hline \multirow{2}{*}{ VARIABLES } & $(1)$ & $(2)$ & $(3)$ \\
ksiEmpAG & ksiEmpind & ksiEmpserv \\
\hline popdiff & $0.0659^{* * *}$ & $0.0104^{* * *}$ & $0.0566^{* * *}$ \\
& $(0.00408)$ & $(0.00128)$ & $(0.00315)$ \\
Observations & $0.148^{* * *}$ & $0.0360^{* * *}$ & $0.101^{* * *}$ \\
Number of countrinum & $(0.0133)$ & $(0.00420)$ & $(0.0103)$ \\
& 208 & 208 & 208 \\
\hline
\end{tabular}

Standard errors in parentheses, $* * * \mathrm{p}<0.01, * * \mathrm{p}<0.05,{ }^{*} \mathrm{p}<0.1$ 
Table 14: FGLS estimates value-added data for IGAD+EAC for [equations (3-2), (3-3) and (3-4)]

\begin{tabular}{lccc}
\hline \multirow{2}{*}{ VARIABLES } & $(1)$ & $(2)$ & $(3)$ \\
incomdiff & ksivaAG & ksivaIND & ksivaSERV \\
& $0.0483^{* * *}$ & $0.0103^{* * *}$ & $0.0595^{* * *}$ \\
popdiff & $(0.00941)$ & $(0.00378)$ & $(0.00874)$ \\
& $0.0645^{* *}$ & $-0.0760^{* * *}$ & $0.231^{* * *}$ \\
Observations & $(0.0296)$ & $(0.0119)$ & $(0.0276)$ \\
Number of countrinum & 189 & 189 & 173 \\
\hline
\end{tabular}

Standard errors in parentheses, $* * * \mathrm{p}<0.01,{ }^{* *} \mathrm{p}<0.05, * \mathrm{p}<0.1$

Table 15: FGLS estimates employment data for SADC [equations (3-5), (3-6) and (3-7)]

\begin{tabular}{|c|c|c|c|}
\hline & (1) & (2) & (3) \\
\hline VARIABLES & ksiEmpAG & ksiEmpind & ksiEmpserv \\
\hline \multirow[t]{2}{*}{ incomdiff } & $0.169 * * *$ & $0.0580 * * *$ & $0.104 * * *$ \\
\hline & $(0.00744)$ & $(0.00347)$ & $(0.00513)$ \\
\hline \multirow[t]{2}{*}{ popdiff } & 0.0102 & $0.0577 * * *$ & $-0.0442 * *$ \\
\hline & $(0.0296)$ & $(0.0138)$ & $(0.0204)$ \\
\hline Observations & 390 & 390 & 390 \\
\hline Number of countrinum & 15 & 15 & 15 \\
\hline
\end{tabular}

Source: Author's estimations, Standard errors in parentheses, ${ }^{* * *} \mathrm{p}<0.01,{ }^{* *} \mathrm{p}<0.05,{ }^{*} \mathrm{p}<0.1$

Table 16: FGLS estimates value-added data for SADC [equations (3-2), (3-3) and (3-4)]

\begin{tabular}{lccc}
\hline \multirow{2}{*}{ VARIABLES } & $(1)$ & $(2)$ & $(3)$ \\
incomdiff & ksivaAG & ksivaIND & ksivaSERV \\
& 0.00774 & $-0.0374^{* * *}$ & $0.0270^{* * *}$ \\
popdiff & $(0.00545)$ & $(0.00805)$ & $(0.00848)$ \\
& -0.00534 & -0.00709 & -0.0228 \\
Observations & $(0.0217)$ & $(0.0320)$ & $(0.0335)$ \\
Number of countrinum & 388 & 388 & 359 \\
\hline
\end{tabular}

Standard errors in parentheses, ${ }^{* * *} \mathrm{p}<0.01,{ }^{* *} \mathrm{p}<0.05,{ }^{*} \mathrm{p}<0.1$ 
After addressing the five regional sub-sets that cover the entire African continent, we find that structural convergence is a reality across the continent. For the robustness check in the next section, we use estimation methods such as the Tobit model, instrumental variables, and Granger non-causality test.

\subsubsection{Robustness check}

\subsubsection{Tobit model}

The dependent variable KSI is bounded below by 0 as shown in Table 2, this may firstly create problems for out-of-sample predictions, secondly, it may also lead to inconsistent parameter estimates if a linear model is fitted to a bounded dependent variable (Wacziarg, 2001). To correct this possible problem, we apply a Tobit model with a left-censoring limit with random effects. The results presented in Tables $\mathbf{1 7}$ and $\mathbf{1 8}$ show that this method also confirms the structural convergence of African economies for both sectoral employment and sectoral value-added data ${ }^{14}$.

Table 17: Tobit model estimates employment data for Africa [equations (3-5), (3-6) and (3-7)]

\begin{tabular}{lccc}
\hline \multirow{2}{*}{ VARIABLES } & $(1)$ & $(2)$ & $(3)$ \\
\hline incomdiff & ksiEmpAG & ksiEmpIND & ksiEmpserv \\
popdiff & $0.00337^{* *}$ & $0.00393^{* * *}$ & -0.000485 \\
& $(0.00149)$ & $(0.000834)$ & $(0.00127)$ \\
Observations & $0.357^{*}$ & 0.125 & 0.0907 \\
Number of countrinum & $(0.202)$ & $(0.0890)$ & $(0.147)$ \\
& 1,248 & 1,248 & 1,248 \\
\hline
\end{tabular}

Standard errors in parentheses, ${ }^{* * *} \mathrm{p}<0.01, * * \mathrm{p}<0.05, * \mathrm{p}<0.1$

\footnotetext{
${ }^{14}$ Except for the services sector for which the incomdiff coefficient is negative but insignificant for the sectoral employment data and not estimated for the sectoral value-added data due to some missing data.
} 
Table 18: Tobit model estimates value-added data for Africa [equations (3-2), (3-3) and (3-4)]

\begin{tabular}{lcc} 
VARIABLES & ksivaAG & ksivaIND \\
\hline incomdiff & $0.00952^{* * *}$ & $0.0107^{* * *}$ \\
popdiff & $(0.00269)$ & $(0.00321)$ \\
& $0.381^{*}$ & -0.0771 \\
Observations & $(0.209)$ & $(0.196)$ \\
Number of countrinum & 1,197 & 1,197 \\
\hline
\end{tabular}

(1)

(2)

Standard errors in parentheses, ${ }^{* * *} \mathrm{p}<0.01,{ }^{* *} \mathrm{p}<0.05,{ }^{*} \mathrm{p}<0.1$

\subsubsection{Instrumental variable (IV) approach}

The meaning of the causality between the reduction in income gaps and the homogeneity of sectoral structures may not be clearly accepted despite the positive link we have highlighted through our estimates. It is easy to accept that the industrial specialization of a country can be both an outcome and a determinant of per capita income. Specialization in high value-added sectors is likely to generate higher incomes than specialization in traditional sectors. Beyond this, there may well be other factors changing over time, such as changes in economic, social, and industrial policies, which affect both industrial structure and incomes that we have not taken into account, but which could bias our estimated coefficients. In order to investigate how these factors may affect our results, and inspired by Barrios, Barry, and Strobl (2002) we use an IV approach. We instrument our independent variable that materializes income convergence incomdiff, with an instrument that materializes the difference in savings per capita between countries (savingcapdiff) ${ }^{15}$. It is easy to see that savings may affect the wealth of a country, but it is unlikely to affect, at least in the short term, the structure of that country's sectors.

To verify the above statements and the validity of the instrument, we perform post-estimation endogeneity tests on the independent variable incomdiff, over and under-identification tests on the instrument savingcapdiff, and heteroscedasticity tests to see the disturbance in the models. Table 19, elaborated by authors, shows the Durbin and Wu-Hausman statistics for the endogeneity tests of the incomdiff variable. The null hypothesis that the incomdiff variable is exogenous is rejected with significant probabilities in all equations except (3-4). Thus, the incomdiff variable is endogenous, which supports the option of relying on a valid

\footnotetext{
${ }^{15}$ This variable is computed in the same way as incomdiff but with per capita saving data
} 
instrument. For equation (3-4) the incomdiff variable can be treated as exogenous, thus the results of our PCSE estimations remain valid.

Table 19: Durbin and Wu-Hausman statistics for endogeneity tests of the incomdiff variable

\begin{tabular}{|c|c|c|c|c|c|c|}
\hline$\underbrace{\text { Equations }}_{\text {statistics }}$ & $(3-5)$ & $(3-6)$ & $(3-7)$ & $(3-2)$ & $(3-3)$ & $(3-4)$ \\
\hline Durbin (score) chi2 (1) & $12.3787 * * *$ & $2.85652 *$ & $23.3375^{* * *}$ & $27.3399 * * *$ & $30.3722 * * *$ & 1.06111 \\
\hline $\begin{array}{l}\text { Wu-Hausman } \\
\mathrm{F}(1,1219)\end{array}$ & $12.2122 * * *$ & $2.79654^{*}$ & $23.2296^{* * *}$ & $27.3011 * * *$ & $30.4079 * * *$ & 1.03611 \\
\hline
\end{tabular}

The results of the IV approach, presented in Tables 20 and 21, elaborated by authors, confirm the structural convergence of the African economies, all the coefficients of incomdiff are positive and significant except for the agricultural sector with value-added data which shows a structural divergence, as its coefficient is negative and significant. The differences in market size maintain the same pattern as with the PCSE estimates. Post-estimation tests such as the Anderson Canon under identification test, the Cragg-Donald Wald F statistic for weak identification test, the Sargan statistic for over-identification test, and the IV heteroscedasticity test show that the instrument is valid and the models do not suffer from heteroscedasticity for all data and sectors.

Table 20: IV estimates employment data for Africa [equations (3-5), (3-6) and (3-7)]

\begin{tabular}{lccc}
\hline \multirow{2}{*}{ VARIABLES } & $(1)$ & $(2)$ & $(3)$ \\
incomdiff & ksiEmpAG & ksiEmpIND & ksiEmpserv \\
popdiff & $0.0302^{* * *}$ & $0.0233^{* * *}$ & $0.0112^{* *}$ \\
& $(0.00611)$ & $(0.00273)$ & $(0.00458)$ \\
Observations & -0.0426 & 0.0181 & $-0.0680^{* *}$ \\
R-squared & $(0.0452)$ & $(0.0202)$ & $(0.0339)$ \\
\hline
\end{tabular}

Standard errors in parentheses, ${ }^{* * *} \mathrm{p}<0.01,{ }^{* *} \mathrm{p}<0.05,{ }^{*} \mathrm{p}<0.1$ 
Table 21: IV estimates value added data for Africa [equations (3-2), (3-3) and (3-4)]

\begin{tabular}{lccc}
\hline VARIABLES & $(1)$ & $(2)$ & $(3)$ \\
ksivaAG & ksivaIND & ksivaSERV \\
\hline incomdiff & $-0.0131^{*}$ & $0.0481^{* * *}$ & $0.0294^{* * *}$ \\
popdiff & $(0.00713)$ & $(0.00714)$ & $(0.00825)$ \\
& $0.197^{* * *}$ & $-0.152^{* * *}$ & $-0.126^{* *}$ \\
Observations & $(0.0522)$ & $(0.0522)$ & $(0.0607)$ \\
R-squared & 1,197 & 1,197 & 1,102 \\
\hline
\end{tabular}

Standard errors in parentheses, $* * * \mathrm{p}<0.01, * * \mathrm{p}<0.05, * \mathrm{p}<0.1$

\subsubsection{Granger non-causality test}

To investigate whether the reduction in income difference (incomdiff) Granger-cause homogeneity in sectoral structures (KSI), a Granger non-causality test is used. The variables incomdiff and KSI are all stationary, so this method can be applied. The results in Tables 22, 23, and 24 estimated by authors show that the null hypothesis that incomdiff does not Granger-cause KSI is rejected with a highly significant probability for all three sectors with employment data ${ }^{16}$. Thus, the alternative hypothesis is accepted which implies that the reduction in income difference Granger-cause homogeneity of sectoral structures for several panels, which is synonymous with structural convergence.

Table 22: incomdiff Granger-causality to ksiEmpAG test results:

Lag order: 1

\begin{tabular}{|c|c|c|}
\hline W-bar $=$ & 6.2806 & \\
\hline Z-bar $=$ & 25.8698 & $(p$-value $=0.0000)$ \\
\hline Z-bar tild & 21.3611 & $(p$-value $=0.0000)$ \\
\hline
\end{tabular}

H0: incomdiff does not Granger-cause ksiEmpAG.

H1: incomdiff does Granger-cause ksiEmpAG for at least one panelvar (countrinum).

${ }^{16}$ For sectoral value-added data, the non-strongly balanced nature of the panel makes estimates impossible. 
Table 23: incomdiff Granger-causality to ksiEmpIND test results:

Lag order: 1

\begin{tabular}{lcl}
\hline $\mathrm{W}$-bar $=$ & 9.1510 & \\
\hline Z-bar $=$ & 39.9318 & $(\mathrm{p}$-value $=0.0000)$ \\
\hline Z-bar tilde $=$ & $33.1964 \quad(\mathrm{p}$-value $=0.0000)$
\end{tabular}

H0: incomdiff does not Granger-cause ksiEmpIND.

H1: incomdiff does Granger-cause ksiEmpIND for at least one panelvar (countrinum).

Table 24: incomdiff Granger-causality to ksiEmpSERV test results:

Lag order: 1

\begin{tabular}{lll}
\hline $\mathrm{W}$-bar $=$ & 5.0863 & \\
\hline Z-bar $=$ & 20.0187 & $(\mathrm{p}$-value $=0.0000)$ \\
\hline Z-bar tilde $=$ & 16.4365 & $(\mathrm{p}$-value $=0.0000)$ \\
\hline
\end{tabular}

H0: incomdiff does not Granger-cause ksiEmpSERV.

H1: incomdiff does Granger-cause ksiEmpSERV for at least one panelvar (countrinum).

\section{CONCLUSION AND POLICY IMPLICATIONS}

Structural convergence among African countries is a topic that has not gained much attention in the literature. The paper contributes to fill this gap by producing a comprehensive survey of the sectoral structural convergence of African countries over the period 1994 to 2019. Based on sectoral employment data, sectoral value-added data, income differences, and market size differences, the paper documented the existence of sectoral structural convergence in Africa, i.e. a greater similarity in sectoral structures while income gaps are narrowing. The occurrence of structural convergence among African countries implies that globally these countries follow similar stages of development characterized by the rise and fall of similar sectors, and those countries can converge towards a structural 'steady state'. Thus, African countries have the opportunity to develop common policies to achieve their latent comparative advantage. Indeed, the growth potential available in Africa should encourage countries to pool their efforts in order to achieve their latent comparative advantage 
by developing and acquiring the human and physical capital required to boost high-value-added activities in the industrial and service sectors. Because the persistence of low-quality human and physical capital would explain the service sector's low productivity and the industrial sector's low labor attractiveness in Africa. This paper could pave way for other aspects of structural convergence in Africa. If data availability permits, attention can be given to intersectoral industry convergence, business cycle synchronization, and trade integration.

\section{APPENDIX:}

List of Countries Understudy

\begin{tabular}{lllll}
\hline Algeria & Congo, Dem. Rep. & Ghana & Mauritius & South Africa \\
Angola & Congo, Rep. & Guinea & Morocco & Sudan \\
Benin & Cote d'Ivoire & Guinea-Bissau & Mozambique & Tanzania \\
Botswana & Djibouti & Kenya & Namibia & Togo \\
Burkina Faso & Egypt, Arab Rep. & Lesotho & Niger & Tunisia \\
Burundi & Equatorial Guinea & Liberia & Nigeria & Uganda \\
Cabo Verde & Eswatini & Madagascar & Rwanda & Zambia \\
Cameroon & Ethiopia & Malawi & Sao Tome and Principe & Zimbabwe \\
Chad & Gabon & Mali & Senegal & \\
Comoros & Gambia, The & Mauritania & Sierra Leone &
\end{tabular}

\section{Regional Economic Communities (RECs) on the African continent}

- Arab Maghreb Union (AMU) was formed by Algeria, Libya, Morocco, and Tunisia, to which we add Egypt.

- Economic Community of Central African States (ECCAS) was formed by Angola, Burundi, Cameroon, Chad, Congo Dem Rep, Congo Rep, Equatorial Guinea, Gabon, Rwanda, and Sao Tome and Principe.

- Economic Community of West African States (ECOWAS) was formed by Benin, Burkina Faso, Cabo Verde, Côte d'Ivoire, Gambia, Ghana, Guinea, Guinea-Bissau, Liberia, Mali, Niger, Nigeria, Senegal, Sierra Leone, and Togo.

- Intergovernmental Authority on Development (IGAD) and the East African Community (EAC) formed by Burundi, Djibouti, Ethiopia, Kenya, Rwanda, Sudan, Tanzania, and Uganda.

- Southern African Development Community (SADC) was formed by Angola, Botswana, Comoros, Congo Dem. Rep, Eswatini, Lesotho, Madagascar, Malawi, Mauritius, Mozambique, Namibia, South Africa, Tanzania, Zambia, and Zimbabwe. 
FUNDING: The authors did not receive any external funding.

CONFLICT OF INTEREST: The authors declare no conflict of interest.

ACKNOWLEDGEMENTS: To Dr. Kouassi Yeboua, Economist and researcher AFIB ISS, Puruweti Siyakiya, phd candidate, Marmara University.

\section{REFERENCES}

1. Abegaz, Berhanu, 2002. "Structural convergence in manufacturing industries between leaders and latecomers." Journal of Development Studies 38 (4 ): 69-99.

https://doi.org/10.1080/00220380412331322421

2. Abegaz, Berhanu, 2008. "The speed of structural convergence in the manufacturing industries of newly industrialising economies." South African Journal of Economics 76: S89-S109.

https://doi.org/10.1111/j.1813-6982.2008.00183.x.

3. Abramovitz, Moses, 1979. "Rapid growth potential and its realisation: the experience of capitalist economies in the postwar period." Economic Growth and Rresources: 1-51.

https://doi.org/10.1007/978-1-349-16173-7_1

4. Abramovitz, Moses, 1986. "Catching up, forging ahead, and falling behind." The Journal of Economic History 46 (2): 385-406. https://doi.org/10.1017/s0022050700046209

5. Albu, Lucian-Liviu, 2012. "Structural Convergence in European Union." Annals-Economy Series, Constantin Brancusi University, Faculty of Economics 4: 1-10.

https://www.utgjiu.ro/revista/ec/pdf/2012-04.II/1_Albu\%20Liviu\%20Lucian.pdf

6. Alexoaei, Alina Petronela, and Raluca Georgiana Robu, 2018. "A theoretical review on the structural convergence issue and the relation to economic development in integration areas." Proceedings of the International Conference on Business Excellence.

7. Amsden, Alice Hoffenberg, 1989. Asia's next giant: South Korea and late industrialization. Oxford University Press on Demand.

8. Barrett, Christopher B, Luc Christiaensen, Megan Sheahan, and Abebe Shimeles, 2017. "On the structural transformation of rural Africa." Journal of African Economies 26 (suppl_1): i1 1-i35. https://doi.org/10.1596/1813-9450-7938

9. Barrios, Salvador, Frank Barry, and Eric Strobl, 2002. "FDI and Structural Convergence in the EU Periphery." Centre for European Policy Research, Workshop and Conferences. 
10. Beck, Krzysztof, 2013. "Structural similarity as a determinant of business cycle synchronization in the European Union: A robust analysis." Research in Economics and Business: Central and Eastern Europe 5 (2). http://www.rebcee.eu/index.php/REB/article/view/48

11. Chenery, Hollis B., 1960. "Patterns of industrial growth." The American economic review 50 (4): 624-654. https://www.jstor.org/stable/1812463

12. Chong, Choy-Yoke, Muzafar Shah Habibullah, Ahmad Zubaidi Baharumshah, and Habshah Midi, 2017. "Structural convergence among ASEAN economies." Advanced Science Letters 23 (9): 87478751. https://doi.org/10.1166/as1.2017.9963

13. Colin, Clark, and Arnold Plant, 1940. "The Conditions of Economic Progress." International Affairs Review Supplement 19 (1). https://doi.org/10.2307/3026172

14. Crespo, Nuno, and Maria Paula Fontoura, 2007. "Integration of CEECs into EU market: structural change and convergence." JCMS: Journal of Common Market Studies 45 (3): 611-632. https://doi.org/10.1111/j.1468-5965.2007.00726.x

15. Cunado, Juncal, and F Pérez De Gracia, 2006. "Real convergence in Africa in the second-half of the 20th century." Journal of Economics and Business 58 (2): 153-167. https://doi.org/10.1016/j.jeconbus.2005.07.002

16. De Vries, Gaaitzen, Marcel Timmer, and Klaas De Vries, 2015. "Structural transformation in Africa: Static gains, dynamic losses." The Journal of Development Studies 51 (6): 674-688. https://doi.org/10.1080/00220388.2014.997222

17. Di Berardino, Claudio, Giuseppe Mauro, Davide Quaglione, and Alessandro Sarra, 2017. "Structural change and the sustainability of regional convergence: Evidence from the Italian regions." Environment and Planning C: politics and space 35 (2): 289-311. https://doi.org/10.1177/0263774x16655800

18. Duarte, Margarida, and Diego Restuccia, 2010. "The role of the structural transformation in aggregate productivity." The Quarterly Journal of Economics 125 (1): 129-173.

https://doi.org/10.1162/qjec.2010.125.1.129

19. Evenson, Robert E, and Larry E Westphal, 1995. "Technological change and technology strategy." Handbook of development economics 3: 2209-2299. https://doi.org/10.1016/s1573-4471(05)80009-9

20. Fagerberg, Jan, 2000. "Technological progress, structural change and productivity growth: a comparative study." Structural change and economic dynamics 11 (4): 393-411. https://doi.org/10.4337/9781788110266.00018

21. Fisher, Allan GB., 1939. "Production, primary, secondary and tertiary." Economic record 15 (1): 2438. https://doi.org/10.1111/j.1475-4932.1939.tb01015.x

22. Fisher, Allan GB. 1952. "A note on tertiary production." The Economic Journal: 820-834. https://doi.org/10.2307/2226528 
23. Forstner, Helmut, and Robert H Balance, 1990. Competing in a Global Economy: An Empirical Study on Specialization and Trade in Manufactures. London: Unwin Hyman Ltd.

24. Fourastié, Jean, 1949. Le grand espoir du XXe siècle : progrès technique, progrès économique, progrès social. Paris: Presses universitaires de France.

25. Gács, János, 2003. "Transition, EU accession and structural convergence." Empirica 30 (3): 271-303. https://doi.org/10.1023/A:1026058430497

26. Gerschenkron, Alexander, 1962. Economic Backwardness in Historical Perspective: A Book of Essays. Cambridge, Mass.: The Belknap Press of Harvard University Press.

27. Grossman, Gene M, and Elhanan Helpman, 1991. Innovation and growth in the global economy. MIT press.

28. Gugler, Klaus, and Michael Pfaffermayr. 2004. "Convergence in structure and productivity in European manufacturing?" German Economic Review 5 (1): 61-79. https://doi.org/10.1111/j.14656485.2004.00094.X

29. Hammouda, Hakim Ben, Stephen N Karingi, Angelica E Njuguna, and Mustapha Sadni Jallab, 2009. "Why doesn't regional integration improve income convergence in Africa?" African Development Review 21 (2): 291-330. https://doi.org/10.1111/j.1467-8268.2009.00211.x

30. Herrendorf, Berthold, Richard Rogerson, and Akos Valentinyi, 2014. "Growth and structural transformation." In Handbook of economic growth, 855-941. Elsevier.

31. Imbs, Jean, 2000. Sectors and the OECD business cycle. Vol. 2473. Centre for Economic Policy Research.

32. Imbs, Jean, and Romain Wacziarg, 2000. "Stages of diversification." 1-41. https://doi.org/10.2139/ssrn.251948

33. Krugman, Paul, 1987. "The narrow moving band, the Dutch disease, and the competitive consequences of Mrs. Thatcher: Notes on trade in the presence of dynamic scale economies." Journal of Development Economics 27 (1-2): 41-55. https://doi.org/10.1016/0304-3878(87)90005-8

34. Krugman, Paul, 1991. Geography and trade. MIT press.

35. Kuznets, Simon, 1972. "Economic Growth of Nations." The Economic Journal 82 (326).

36. Lall, Sanjaya, 1997. Learning from the Asian tigers: Studies in technology and industrial policy. New York: St. Martin's Press.

37. Landesmann, Michael, 2000. Structural Change in the Transition Economies, 1989 to 1999. WIIW Research Report. https://www.econstor.eu/handle/10419/204043

38. Lazarev, Valery, and Paul Gregory, 2007. "Structural convergence in Russia's economic transition, 1990-2002." Economic Change and Restructuring 40 (3): 281-304. https://doi.org/10.1007/s10644007-9033-1

39. Lewis, William Arthur, 1954. "Economic development with unlimited supplies of labour." The Manchester School 22 (2): 139-191. https://doi.org/10.1111/j.1467-9957.1954.tb00021.x 
40. Lin, Justin Yifu, 2011. "New structural economics: A framework for rethinking development." The World Bank Research Observer 26 (2): 193-221. https://doi.org/10.1093/wbro/lkr007

41. Lin, Justin Yifu, and Célestin Monga, 2010. "Growth identification and facilitation." World Bank Policy Research Working Paper 5313. https://doi.org/10.1596/1813-9450-5313

42. Longhi, Christian, and Antonio Musolesi, 2007. "European cities in the process of economic integration: towards structural convergence." The Annals of Regional Science 41 (2): 333-351. https://doi.org/10.1007/s00168-007-0117-7

43. Longhi, Simonetta, Peter Nijkamp, and Lulia Traistaru, 2004. "Economic Integration and Regional Structural Change in a Wider Europe: Evidence from New EU and Accession Countries." Journal for Institutional Innovation, Development \& Transition 8: 48-55.

https://research.vu.n1/en/publications/economic-integration-and-regional-structural-change-in-a$\underline{\text { wider-eu }}$

44. Marelli, Enrico, and Marcello Signorelli, 2010. "Institutional, nominal and real convergence in Europe." Banks \& bank systems (5, Iss. 2 (cont.)): 140-155.

https://www.researchgate.net/publication/229117191_Institutional_nominal and real_convergence i n_Europe

45. McMillan, Margaret S, and Kenneth Harttgen, 2014. What is Driving the 'African Growth Miracle'? National Bureau of Economic Research.

46. McMillan, Margaret S, and Dani Rodrik, 2011. Globalization, structural change and productivity growth. National Bureau of Economic Research.

47. McMillan, Margaret S, and Albert Zeufack, 2021. Labor Productivity Growth and Industrialization in Africa. National Bureau of Economic Research.

48. O'Leary, Eoin, 2003. "Aggregate and sectoral convergence among Irish regions: the role of structural change, 1960-96." International Regional Science Review 26 (4): 483-501. https://doi.org/10.1177/0160017603259179

49. Pack, Howard, 2000. "Industrial policy: growth elixir or poison?" The World Bank Research Observer 15 (1): 47-67. https://doi.org/10.1093/wbro/15.1.47

50. Page, John, 2012. "Can Africa Industrialise?" Journal of African Economies 21 (suppl_2): ii86-ii124. https://doi.org/10.1093/jae/ejr045

51. Palan, Nicole, and Claudia Schmiedeberg, 2010. "Structural convergence of European countries." Structural Change and Economic Dynamics 21 (2): 85-100.

https://doi.org/10.1016/j.strueco.2010.01.001

52. Puga, Diego, and Anthony J Venables, 1997. "Agglomeration and Economic Development: Import Substitution vs. Trade Liberalisation." Readings in developement economics 1 (10): 271-295. https://diegopuga.org/papers/dp0377.pdf 
53. Ramsey, Frank Plumpton, 1928. "A mathematical theory of saving." The Economic Journal 38 (152): 543-559. https://doi.org/10.2307/2224098

54. Ray, Debraj, 1998. Development economics. Princeton University Press.

55. Redding, Stephen, 1999. "Dynamic comparative advantage and the welfare effects of trade." Oxford economic papers 51 (1): 15-39. https://doi.org/10.1093/oep/51.1.15

56. Rodrik, Dani, 2014. "An African growth miracle?". https://doi.org/10.3386/w20188

57. Ruttan, Vernon W., 2000. "Technology, Growth, and Development: An Induced Innovation Perspective." OUP Catalogue. https://www.semanticscholar.org/paper/Technology\%2C-Growth\%2Cand-Development\%3A-An-Induced-Ruttan/9dac2f0382c606997dff970353da1287b1351a27

58. Sazanami, Yoko, 1995. "The East Asian Miracle: Economic Growth and Public Policy. A World Bank Policy Research Report. London: Oxford University Press, 1993. xvii, 289 pp." Cambridge University Press 54 (1). https://doi.org/10.2307/2058969

59. Solow, Robert M., 1956. "A contribution to the theory of economic growth." The Quarterly Journal of Economics 70 (1): 65-94. https://doi.org/10.2307/1884513

60. Solow, Robert M., 1957. "Technical change and the aggregate production function." The review of Economics and Statistics 39 (3): 312-320. https://doi.org/10.2307/1926047

61. Strat, Vasile Alecsandru, and Oana Cristina Popovici, 2015. "FDI Convergence versus Real and Structural Convergence at the EU Level. An Approach Based on the GINI Coefficient." Economia. Seria Management 18 (1): 150-162. https://www.researchgate.net/profile/OanaPopovici/publication/282604834 FDI_Convergence versus Real and Structural Convergence at th e EU_Level_An_Approach Based on the GINI_Coefficient/links/561383e608aea9fb51c31769/FDI -Convergence-versus-Real-and-Structural-Convergence-at-the-EU-Level-An-Approach-Based-on-theGINI-Coefficient.pdf

62. Syrquin, Moises, and Hollis Burnley Chenery, 1989. Patterns of Development, 1950 to 1983. Vol. 41: Citeseer.

63. Timmer, Marcel P., 1998. Catch up patterns in newly industrializing countries. An international comparison of manufacturing productivity in Taiwan 1961-1993. Groningen Growth and Development Centre, Groningen.

64. Veblen, Thorstein, 1915. Imperial Germany and the Industrial Revolution.: BW Huebsch. NewYork; London: The Macmillan Company.

65. Vernon, Raymond, 1989. "Technological development." World Bank Publ. Washington. DC: 37. https://www.amazon.com/Technological-Development-Historical-Experience$\underline{\text { Seminar/dp/082131162X }}$

66. Viner, Jacob, 1950. The Customs Union Issue. Oxford: Oxford University Press.

67. Wacziarg, Romain, 2001. Structural convergence. Stanford University. 